\title{
Oxidative Burst Elicited by Bacillus mycoides Isolate Bac J, a Biological Control Agent, Occurs Independently of Hypersensitive Cell Death in Sugar Beet
}

\author{
Rebecca L. Bargabus, Nina K. Zidack, John E. Sherwood, and Barry J. Jacobsen \\ Department of Plant Science and Plant Pathology, Montana State University, 119 AgBioSciences Facility, Bozeman \\ 59717-3150, U.S.A.
}

Submitted 17 June 2003. Accepted 22 August 2003.

\begin{abstract}
Response of sugar beet cultivars C40 and USH11 to syringe infiltration of live and dead Bacillus mycoides isolate Bac $\mathbf{J}$, a biological control agent, and virulent and avirulent isolates of Erwinia carotovora pv. betavasculorum was measured by monitoring systemic acquired resistance control of Cercospora beticola, specific activity of chitinase and $\beta$-glucanase, the oxidative burst, and hypersensitive cell death at the infiltration site. Priming sugar beet with $B$. mycoides Bac $J\left(1 \times 10^{8}\right.$ cells $\left./ \mathrm{ml}\right)$ and avirulent isolates of $E$. carotovora pv. betavasculorum $\left(1 \times 10^{6}\right.$ cells $\left./ \mathrm{ml}\right)$ reduced $C$. beticola symptoms by nearly $70 \%$ on distal, untreated leaves. Systemic resistance responses elicited by live $B$. mycoides Bac $J$ and avirulent $E$. carotovora pv. betavasculorum isolates, measured by assays for chitinase and $\beta$-glucanase, were statistically equivalent, and biphasic hydrogen peroxide production was observed. Although similar in timing, the second hydrogen peroxide burst was twofold lower for $B$. mycoides Bac J than for avirulent $E$. carotovora pv. betavasculorum. Hypersensitive cell death was elicited by avirulent $E$. carotovora pv. betavasculorum but not $B$. mycoides Bac J. An oxidative burst was elicited by spray-applied $B$. mycoides Bac $J$ under both light and green light conditions, indicating that the signal produced by $B$. mycoides Bac J was not reliant on the stomata for entry into sugar beet. $A$ working model for signal delivery and systemic resistance induction by $B$. mycoides Bac $\mathrm{J}$ in sugar beet is proposed.
\end{abstract}

The oxidative burst is one of the earliest events in plant defense responses (Costet et al 2002). It is marked by the production of active oxygen species (AOS) through four sequential, one-electron reductions of dioxygen to water (Hippeli et al. 1999). The AOS include, in order of least to most reactive and longest to shortest lived, hydrogen peroxide, superoxide anion, and hydroperoxyl and hydroxyl radicals (Boveris 1998).

AOS are produced in both compatible and incompatible plant-pathogen interactions (Baker and Orlandi 1995; Glazener et al. 1996; Jabs et al. 1997; Wolfe et al. 2000). The production of hydrogen peroxide and superoxide anion also has been observed in rhizobium-plant interactions (Santos et al. 2001). However, the role of AOS in elicitation of induced resistance by biological control agents has not yet been elucidated. In a compatible plant-pathogen interaction, a single, rapid burst of hydrogen peroxide is observed (Grant and Loake 2000). This response is believed to be due to the perception by the host of

Corresponding author: B. J. Jacobsen; Telephone: 406-994-5161; Fax: 406-994-7600; E-mail: uplbj@ montana.edu generic pathogen constituents, such as fungal glucans, chitins, or chitosans (Boller 1995), the conserved N-terminal region of bacterial flagella (Felix et al. 1999), or viral coat proteins (Allan et al. 2001). The transient primary burst is nonspecific and has no effect on disease progression (van Breusegem et al. 2001). During incompatible interactions, a second, more prolonged peak of hydrogen peroxide production quickly follows the initial burst as a result of specific gene-for-gene recognition (Baker and Orlandi 1995; Levine et al. 1994).

Biphasic production of AOS at the attempted sites of avirulent pathogen infection is significant for several reasons. Hydrogen peroxide is needed in the physical strengthening of plant cell walls through peroxidase-catalyzed lignification (Hammerschmidt and Kuc 1982) and cell wall protein crosslinking (Bradley et al. 1992; Lamb and Dixon 1997). This bolstering of the physical barrier makes it harder for pathogens to penetrate plant cells by way of enzymatic digestion. AOS also are directly toxic to microorganisms (Gilchrist 1998; Imlay 2002; Levine et al. 1996) and inhibitory toward fungal spore germination (Peng and Kuc 1992). Additionally, AOSmediated lipid peroxidation of cell membranes can lead to plant cell death (Bradley et al. 1992; Grant and Loake 2000; Jalloul et al. 2002). This localized programmed cell death serves to prevent nutrient acquisition and pathogen spread (Parker and Coleman 1997). Hydrogen peroxide can diffuse freely across cell membranes, and therefore, has been implicated in the signaling for the establishment of downstream plant immunity events (Levine et al. 1994). Often, in conjunction with nitric oxide, hydrogen peroxide can stimulate production of salicylic acid biosynthetic enzymes (Chen et al. 1993) and pathogenesis-related proteins (Alvarez et al. 1998; Bi et al. 1995; Mackerness et al. 2001; van Breusegem et al. 2001; van Camp et al. 1998), two key players in plant systemic resistance (van Loon and van Strein 1999). Previously, biphasic hydrogen peroxide production was thought to orchestrate hypersensitive cell death (Alvarez 1998, Levine at al. 1994, 1996). However, several recent examples have shown that the oxidative burst and hypersensitive response can occur independently of one another (Dorey et al. 1999; Glazener et al. 1996).

In previous work, we have shown that Bacillus mycoides isolate Bac $\mathrm{J}$ is capable of eliciting systemic induced resistance in sugar beet (Beta vulgaris L.). We had speculated that an oxidative burst precedes induction due to the downstream involvement of pathogenesis-related proteins (Bargabus et al. 2002) and other preliminary results (Bargabus et al. 2001). The objectives of the research reported here were to further characterize the oxidative burst elicited in sugar beet by the biological control agent Bacillus mycoides Bac J. Additional objectives 
were to determine if the oxidative burst was consistent in timing and intensity with that elicited by avirulent Erwinia carotavora pv. betavasculorum and to determine if the oxidative burst was accompanied by sugar beet cell death.

\section{RESULTS}

\section{Disease control.}

Previous studies have shown $1 \times 10^{8}$ B. mycoides Bac J cells/ml effectively reduce Cercospora beticola disease severity; therefore, varying cell concentrations of E. carotovora pv. betavasculorum isolates 1 and 6 were syringe infiltrated into sugar beet leaves to determine the concentrations that would reduce $C$. beticola disease symptoms to a statistically equivalent level. This allowed for direct comparison of the oxidative burst results obtained for B. mycoides Bac J and the two Erwinia isolates. Only the incompatible interactions of $E$. carotovora pv. betavasculorum isolates 1 and 6 with $B$. vulgaris cvs. C40 and USH11, respectively, resulted in statistically signifi-
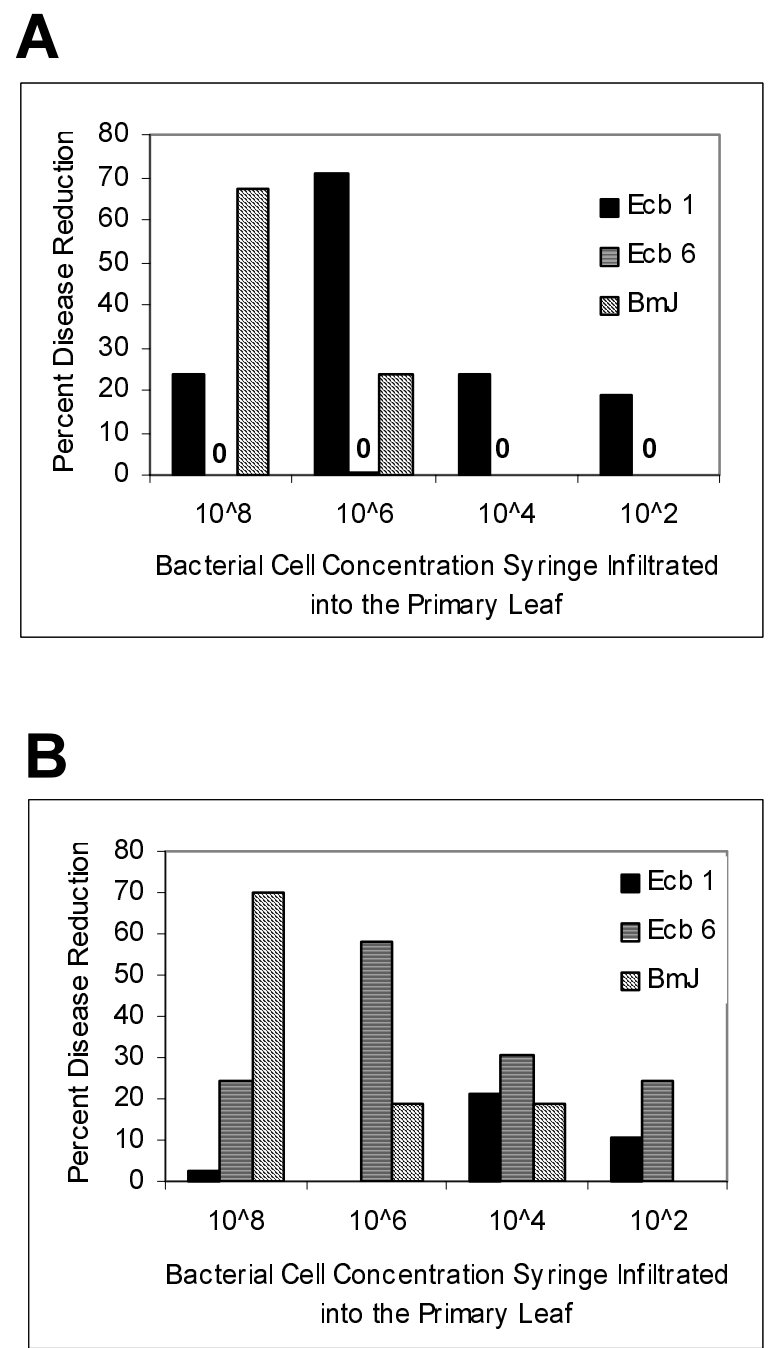

Fig. 1. Systemic reduction of Cercospora leaf spot symptoms on sugar beet compared with a water-treated control following priming with Erwinia carotovora pv. betavasculorum isolates 1 (Ecb 1) and 6 (Ecb 6) or Bacillus mycoides isolate Bac $\mathrm{J}(\mathrm{BmJ})$ on two sugar beet cultivars, A, C40 and B, USH11. Data are the mean of three independent experiments containing five replicates per treatment. Treatments demonstrating a statistically significant decrease in disease severity compared with the water-treated control are designated with an asterisk $(*)$. Treatments that showed no reduction in disease severity compared with the water-treated control are designated with a zero (0). Ecb 1 and Ecb 6 are avirulent on C40 and USH11, respectively. cant $C$. beticola disease reduction (Fig. 1A and B). Of the four E. carotovora pv. betavasculorum cell concentrations tested, 1 $\times 10^{6}$ cells $/ \mathrm{ml}$ provided the greatest level of $C$. beticola symptom reduction on systemic, untreated leaves (Fig. 1A and B). This reduction in disease symptoms, $\approx 70 \%$, was statistically equivalent to the systemic disease control afforded by syringe infiltration of Bacillus mycoides Bac $\mathrm{J}$ at $1 \times 10^{8} \mathrm{CFU} / \mathrm{ml}$ (Fig. $1 \mathrm{~A}$ and $\mathrm{B}$ ). The incompatible interactions also reduced $C$. beticola symptoms when $1 \times 10^{8}$ and $1 \times 10^{4}$ cells/ml were syringe infiltrated; however, this reduction was statistically lower than that achieved with $1 \times 10^{8}$ B. mycoides Bac J cells $/ \mathrm{ml}$. Syringe infiltration of $1 \times 10^{6} \mathrm{~B}$. mycoides $\mathrm{Bac} \mathrm{J}$ cells $/ \mathrm{ml}$ reduced $C$. beticola symptoms $\approx 25 \%$. Compatible interactions (E. carotovora pv. betavasculorum isolate 1 on USH11 and isolate 6 on C40) did not reduce $C$. beticola disease symptoms at any cell concentration tested (Fig. 1A and B). B. pumulis isolate BMH5E-40 and dead B. mycoides Bac J cells did not reduce $C$. beticola disease symptoms (data not shown).

Induction of pathogenesis-related proteins in sugar beet.

Standard inoculation methods for $B$. mycoides Bac $\mathrm{J}$ and the E. carotovora pv. betavasculorum isolates previously have differed; therefore, three inoculation methods (stab inoculation, syringe infiltration, and spray application) were examined to determine which treatment provided the most consistent level of induction of pathogenesis-related proteins by B. mycoides Bac $\mathrm{J}$ and the two Erwinia isolates. Increased production of pathogenesis-related proteins previously have been shown to serve as markers for systemic resistance induction in sugar beet (Bargabus et al. 2002). Of the three treatment methods employed, syringe infiltration provided the most consistent induction of the sugar beet pathogenesisrelated proteins chitinase and $\beta$-glucanase following treatment with the avirulent E. carotovora pv. betavasculorum isolates and B. mycoides Bac J. Although the chitinase activity was slightly higher following $B$. mycoides Bac J treatment when compared with the incompatible interactions, the resultant $\beta$-glucanase activity was statistically equivalent. With both pathogenesis-related proteins, the activities were approximately twofold greater than found in the water-treated controls (Table 1). The petiole stab treatment was effective at inducing both pathogenesis-related proteins in the incompatible interactions (Table 1). B. mycoides Bac J was moderately effective with stab inoculation and led to a slight induction of chitinase activity when compared with the water control; however, on both cultivars, the induction level was statistically lower than that elicited by the incompatible interactions (Table 1). B. mycoides Bac J stab inoculation did not induce $\beta$-glucanase in either cultivar (Table 1). Spray application of $B$. mycoides Bac J elicited a statistically significant induction of both pathogenesis-related proteins. However, that treatment was ineffective at inducing $\beta$-glucanase using $E$. carotovora pv. betavasculorum isolate 1 on $\mathrm{C} 40$ (Table 1). E. carotovora pv. betavasculorum isolate 6 , when spray applied to USH11, elicited a statistically significant increase in $\beta$-glucanase activity when compared with the water-infiltrated control, although it was statistically lower than the level induced by $B$. mycoides Bac J (Table 1). Both incompatible interactions led to an induction of chitinase activity. However, in both instances, the induction level was lower than that observed following $B$. mycoides Bac J infiltration. Treatment with water and the virulent pathogens, regardless of the method, rarely resulted in a statistically significant increase in chitinase- or $\beta$-glucanase-specific activity (Table 1). B. pumulis isolate BMH5E-40 and dead B. mycoides Bac J did not result in a statistically significant increase in pathogenesisrelated protein activity (data not shown). 
The oxidative burst of sugar beet.

Induction of an oxidative burst was examined using phenol red oxidation. Biphasic hydrogen peroxide production was observed in both incompatible interactions (Fig. 2A and B). In both instances, the primary burst was observed within $15 \mathrm{~min}$ and peaked at approximately $2.5 \mathrm{mM} \mathrm{H}_{2} \mathrm{O}_{2}$ (Fig. 2A and B). Statistically equivalent primary peaks were observed with both compatible and incompatible interactions, live and dead $B$. mycoides Bac J treatment, and B. pumulis isolate BMH5E-40 infiltration (Fig. 2A and B). Both incompatible interactions elicited a secondary burst, absent in the compatible interactions and with dead B. mycoides Bac $\mathrm{J}$ and B. pumulis isolate BMH5E-40 infiltration. This burst occurred at approximately 2 $\mathrm{h}$ post syringe infiltration and peaked at approximately $4 \mathrm{mM}$ $\mathrm{H}_{2} \mathrm{O}_{2}$ (Fig. 2A and B). B. mycoides Bac J elicited a secondary burst from both sugar beet cultivars. Although the timing was identical to that observed in the incompatible interactions, the $\mathrm{H}_{2} \mathrm{O}_{2}$ concentration was statistically lower at approximately $2.5 \mathrm{mM}$ (Fig. 2A and B).

\section{Signaling in B. mycoides Bac J-sugar beet interactions.}

It was determined previously that $B$. mycoides $\mathrm{Bac} \mathrm{J}$ is an epiphyte on sugar beet (Bargabus et al. 2002); therefore, signals for the establishment of systemic resistance must be able to enter in through the plant leaf. To examine the possible role of stomata in the relaying of signals, the oxidative burst following spray application of $B$. mycoides Bac $\mathrm{J}$ in the dark was observed. Treatment of sugar beet with any microorganism, regardless of systemic resistance induction capability, resulted in a primary burst of hydrogen peroxide; therefore, in this case, observations were limited to the secondary hydrogen peroxide burst (Fig. 3B). The secondary peak elicited in sugar beet by $B$. mycoides Bac $\mathrm{J}$ under green light conditions was statistically equivalent to that elicited by $B$. mycoides Bac $\mathrm{J}$ in the light (Fig. 3A). Prior to analysis of phenol red oxidation, the stomata were observed. Under green light conditions, the stomata were closed within $15 \mathrm{~min}$; in the light, the stomata remained open (data not shown).

\section{Cell death in sugar beet.}

Both the compatible and the incompatible interactions resulted in sugar beet cell death. In the former case, necrotic death of the infiltrated tissue was observed within 1 week following treatment, followed by systemic spread of the pathogen (data not shown). In the latter case, a discrete hypersensitivelike lesion formed in the immediate area in and around the infiltration site within 1 week following treatment that appeared to prevent the systemic spread of the pathogen (Fig. 4A through F). Regardless of the incubation time, B. mycoides Bac $\mathrm{J}$ infiltration failed to result in any cell death beyond that observed with the water control (Fig. 4A through F).

\section{DISCUSSION}

Induction of systemic plant defense responses has been observed in several plants following treatment with pathogens (Hutchenson 1998; Kuc 1992), biological control agents (Bargabus et al. 2002; Pal et al. 2001; van Loon and Pieterse 2002), phytohormones (Cohen 2002), and chemicals (Tally et al. 1999). The typical means of demonstrating induction of these responses is through challenge assays in which distal, untreated leaves are challenged with a pathogen following a short priming period with an inducing agent on a primary, spatially separated leaf or root system (Conrath et al. 2002). These experiments often are followed by characterization of pathogenesis-related proteins that are molecular markers of systemic resistance induction (van Loon and van Strein 1999). In this study, treatment with live B. mycoides Bac J or avirulent Erwinia isolates resulted in significant disease control of $C$. beticola on sugar beet (Fig. 1). Additionally, live B. mycoides Bac J and avirulent $E$. carotovora pv. betavasculorum treatment resulted in a twofold increase in chitinase- and $\beta$-glucanase-specific activity, indicative of systemic resistance induction (Table 1).

One hundred times more B. mycoides Bac J cells were required to elicit disease control statistically equivalent to that of the incompatible E. carotovora pv. betavasculorum-sugar beet interactions. Furthermore, cellular responsive differences in sugar beet between B. mycoides Bac J and E. carotovora pv. betavasculorum were exemplified by the different responses induced by the treatment methods as measured by chitinase and $\beta$-glucanase activity. Stab inoculation, which limits the cell concentration, was not an effective means to inoculate $B$. mycoides Bac $\mathrm{J}$ because no induction of systemic resistance

Table 1. Systemic-specific activities of two pathogenesis-related proteins following various treatment methods with Erwinia carotavora pv. betavasculorum isolates 1 and 6 , water, and Bacillus mycoides isolate Bac $\mathrm{J}$

\begin{tabular}{|c|c|c|c|c|c|c|}
\hline \multirow[b]{3}{*}{ Treatments $^{\mathbf{b}}$} & \multicolumn{6}{|c|}{ Tests on cultivars ${ }^{\mathrm{a}}$} \\
\hline & \multicolumn{2}{|c|}{ Stab } & \multicolumn{2}{|c|}{ Syringe } & \multicolumn{2}{|c|}{ Spray } \\
\hline & $\mathbf{C 4 0}$ & USH11 & $\mathbf{C 4 0}$ & USH11 & $\mathbf{C 4 0}$ & USH11 \\
\hline \multicolumn{7}{|c|}{ Chitinase-specific activity $^{\mathrm{c}}$} \\
\hline Water & 1.56 & 1.52 & 1.22 & 1.53 & 1.22 & 1.53 \\
\hline \multicolumn{7}{|c|}{ E. carotavora pv. betavasculorum } \\
\hline Isolate 1 & 2.36 & 1.66 & 2.90 & 1.66 & 1.78 & 1.59 \\
\hline Isolate 6 & 2.06 & 2.30 & 1.40 & 2.70 & 1.35 & 2.79 \\
\hline B. mycoides Bac J & 2.05 & 1.91 & 3.33 & 3.17 & 2.70 & 3.56 \\
\hline $\operatorname{LSD}(0.05)$ & 0.28 & 0.26 & 0.31 & 0.28 & 0.21 & 0.37 \\
\hline \multicolumn{7}{|c|}{$\beta$-Glucanase-specific activity ${ }^{\mathrm{d}}$} \\
\hline Water & 39.3 & 58.2 & 41.9 & 64.3 & 37.4 & 49.8 \\
\hline \multicolumn{7}{|c|}{ E. carotavora pv. betavasculorum } \\
\hline Isolate 1 & 47.7 & 68.0 & 85.4 & 74.9 & 25.7 & 59.7 \\
\hline Isolate 6 & 45.5 & 75.8 & 42.1 & 114.3 & 34.6 & 93.7 \\
\hline B. mycoides Bac J & 36.1 & 66.8 & 88.9 & 103.2 & 49.5 & 121.5 \\
\hline $\operatorname{LSD}(0.05)$ & 6.0 & 11.6 & 20.3 & 13.0 & 11.9 & 26.1 \\
\hline
\end{tabular}

${ }^{a}$ Sugar beet (Beta vulgaris) cvs. C40 and USH11 were tested for reactivity to both E. carotavora pv. betavasculorum isolates and Bacillus mycoides Bac J.

${ }^{\mathrm{b}} \mathrm{E}$. carotavora pv. betavasculorum isolates 1 and 6 were applied at $1 \times 10^{6}$ cells $/ \mathrm{ml}$ and are avirulent on cvs. C40 and USH11, respectively. B. mycoides Bac $\mathrm{J}$ was applied at $1 \times 10^{8}$ cells $/ \mathrm{ml}$. LSD $=$ least significant difference (probability $=0.05$ )

${ }^{\mathrm{c}}$ Chitinase-specific activity determined by chitinase plate assay is expressed as milligrams of N-acetyl-D-glucosamine released per hour per milligram of apoplastic protein. The data is the mean of three independent experiments containing three replicates for each treatment.

${ }^{\mathrm{d}} \beta$-Glucanase-specific activity as determined by laminarin digestion is expressed as micrograms of glucose released per minute per milligram of apoplastic protein. The data is the mean of three independent experiments containing three replicates for each treatment. 
was observed, whereas it was a very effective inoculation method for induction of systemic resistance markers in incompatible interactions. On the other hand, syringe infiltration and spray application of $B$. mycoides Bac J, both of which deliver high cell titers, were effective methods for the induction of chitinase and $\beta$-glucanase (Table 1 ).

The large discrepancy in $B$. mycoides Bac $\mathrm{J}$ and avirulent $E$. carotovora pv. betavasculorum cell concentration requirements for systemic resistance elicitation may be due to differences in pathogen signal delivery or plant signal recognition. Erwinia spp. are gram-negative bacteria that assemble type III secretion systems for the intracellular delivery of signals, including $a v r$

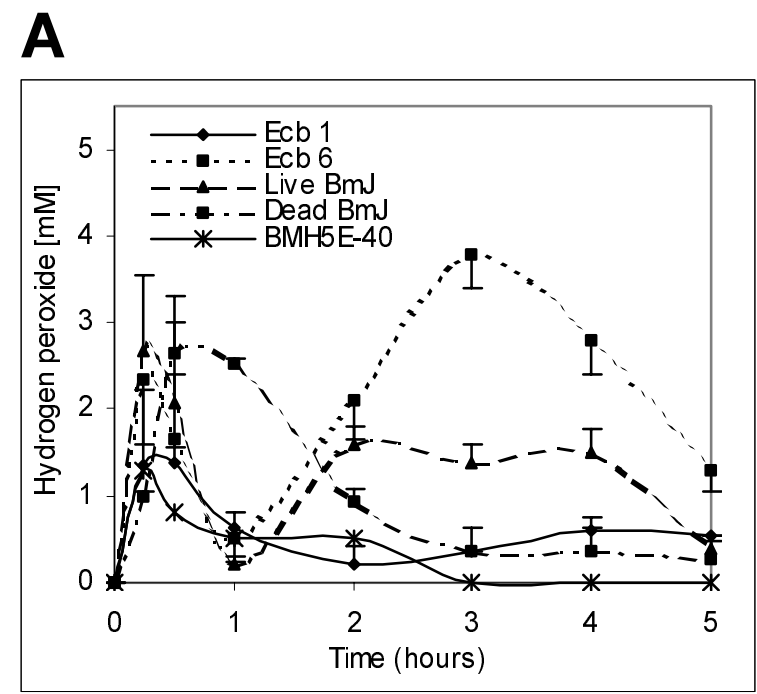

B

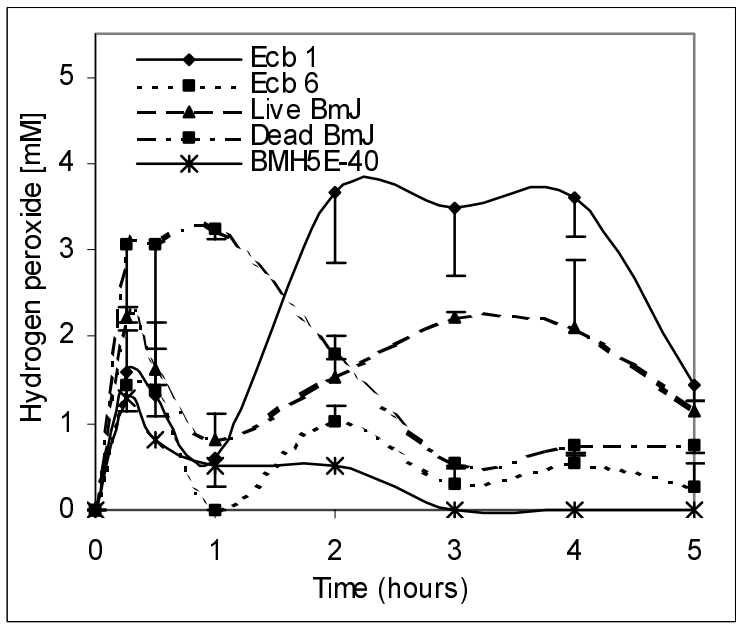

Fig. 2. Hydrogen peroxide produced by two cultivars of sugar beet as determined by phenol red oxidation. A, Amount of hydrogen peroxide produced by 12 USH11 leaf disks following syringe infiltration with Erwinia carotavora pv. betavasculorum isolates 1 (Ecb 1; virulent) and 6 (Ecb 6; avirulent) at $1 \times 10^{6}$ cells $/ \mathrm{ml}$, and live and dead Bacillus mycoides isolate $\mathrm{Bac} \mathrm{J}(\mathrm{BmJ})$ and B. pumulis isolate BMH5E-40 (BMH5E40) at $1 \times 10^{8}$ cells/ml, after subtracting the background phenol red oxidation produced in plants syringe infiltrated with water only. The data is the mean of three independent experiments containing two replicates for each treatment. B, Amount of hydrogen peroxide produced by $12 \mathrm{C} 40$ leaf disks following syringe infiltration with Ecb 1 (avirulent) and Ecb 6 (virulent) at $1 \times 10^{6}$ cells $/ \mathrm{ml}$, and live and dead BmJ and BMH5E-40 at 1 $\times 10^{8}$ cells $/ \mathrm{ml}$, after subtracting the background phenol red oxidation produced in plants syringe infiltrated with water only. The data is the mean of three independent experiments containing two replicates for each treatment. gene products (Kariola et al. 2003; Venisse et al. 2002). Certain constituents found in the apoplast stimulate $h r p$ gene activation needed for type III secretion system formation (Rahme et al. 1992), without which certain pathogenesis-related proteins cannot be produced (Kariola et al. 2003). Interestingly, spray application of avirulent E. carotovora pv. betavasculorum isolates was the only approach that was ineffective at inducing resistance in sugar beet with the incompatible interactions, presumably because cues for type III secretion system development were not available through external application. $B$. mycoides Bac J, a gram-positive, epiphytic bacterium, lacks the capability to form such specialized delivery machinery. However, we have hypothesized that the sugar beet receptor or receptors for $B$. mycoides Bac $\mathrm{J}$ perception are either cytosolic or plasma-membrane bound (Fig. 5), because the oxidative burst, the earliest response in the establishment of plant immunity (Grant and Loake 2000), is identical when using protoplasts or leaf disks (data not shown). Therefore, our hypothesized means of entry for the B. mycoides Bac $\mathrm{J}$ signal is either
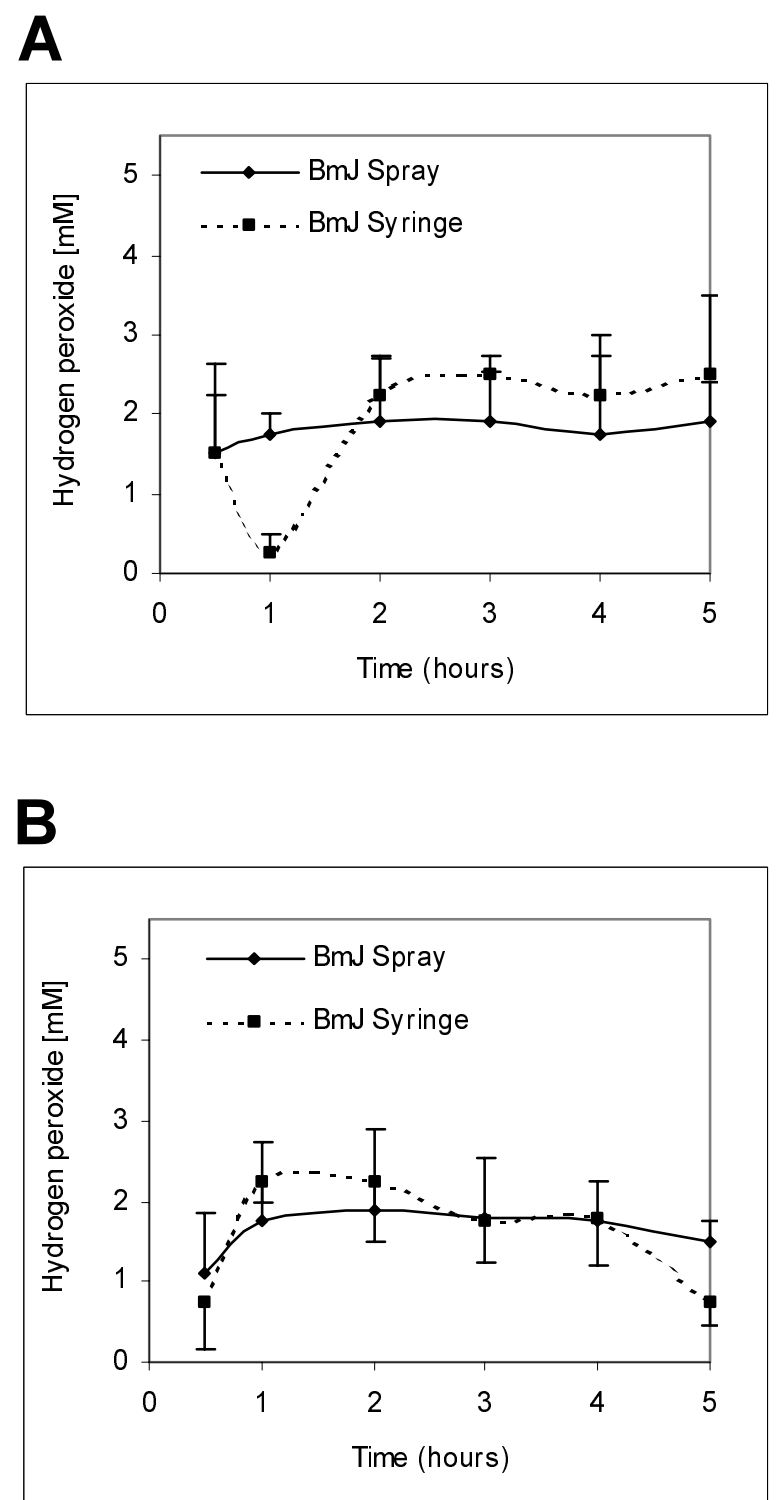

Fig. 3. Secondary peak of hydrogen peroxide produced by sugar beet, as measured using phenol red oxidation, following spray application or syringe infiltration of Bacillus mycoides isolate Bac $\mathbf{J}(\mathrm{BmJ}) \mathbf{A}$, in the light and $\mathbf{B}$, dark after subtracting the background phenol red oxidation produced in plants with water spray applied and syringe infiltrated respectively. 
acquisition through the stomata or diffusion through the cuticle and cell wall (Fig. 5). The former has been eliminated as a possible means of entry due to the observed oxidative burst with B. mycoides Bac J treatment in green light, where a clear secondary burst occurred even when the stomata were closed. An alternate explanation for inefficient signaling in B. mycoides Bac J-sugar beet interactions could be due to imperfect recognition of the signal by sugar beet as a result of an imperfect fit between the receptor and the signal molecules. This could lead to a weak induced resistance state when cell concentrations are limited. These hypotheses are based on one major assumption: that sugar beet has an innate means of detecting the signal produced by $B$. mycoides Bac J. In this case, both cultivars re-
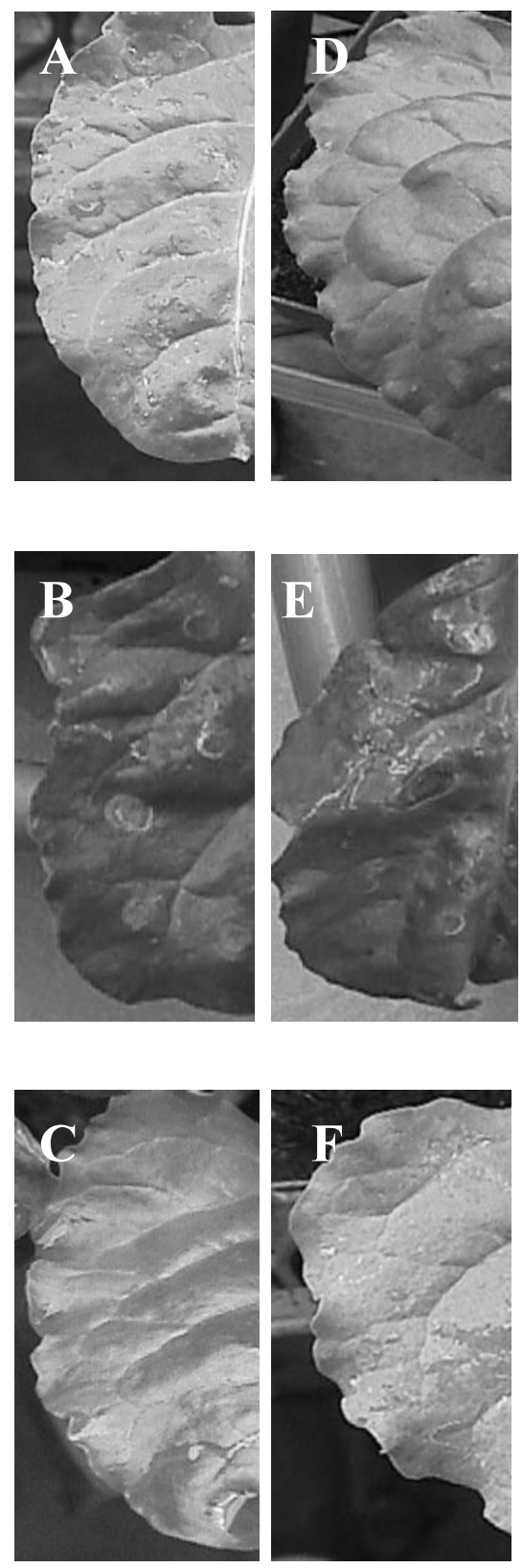

Fig. 4. Response of sugar beet leaves following syringe infiltration with A and D, water, Erwinia carotovora pv. betavasculorum isolates $\mathbf{B}, 1$ and $\mathbf{E}, 6$, and $\mathbf{C}$ and $\mathbf{F}$, Bacillus mycoides isolate Bac $\mathrm{J}$ on sugar beet cultivars A through $\mathbf{C}, \mathbf{C} 40$ and $\mathbf{D}$ through $\mathbf{F}$, USH11. B and E, Incompatible interactions resulted in localized hypersensitive-like cell death (indicated by arrows). Compatible interactions (data not shown) resulted in necrosis and eventual systemic spread of the pathogen. $\mathbf{C}$ and F, Biological control agent and $\mathbf{A}$ and $\mathbf{D}$, water infiltration resulted in no macro- or microscopic cell death. sponded to treatment with B. mycoides Bac J equally well, suggesting that, if a receptor for $B$. mycoides Bac $\mathrm{J}$ exists, it is conserved in $\mathrm{C} 40$ and USH11.

B. mycoides Bac $\mathrm{J}$ is nonpathogenic and, therefore, poses no real threat to sugar beet, yet sugar beet exhibits biochemical changes that are characteristic of avirulent pathogen-plant interactions. There is one published account of B. mycoides causing bacteriosis of sugar beet at varying developmental stages (Stankiewicz and Krezel 1984). It is possible that these observations were made using a different $B$. mycoides isolate or sugar beet cultivar. B. mycoides Bac $\mathrm{J}$ treatment has not resulted in disease on cultivars C40, USH11, Seedex, or Holly Hybrid 88; therefore, the former seems more likely. Additionally, B. mycoides is not included as a pathogen in the Compendium of Beet Diseases and Insects (Whitney and Duffus 1991). Plants contain several recognition mechanisms for other nonpathogenic microorganisms, such as mycorrhizal fungi and rhizobia. In fact, the formation of mycorrhizal associations also has been shown to induce systemic resistance (Feugey et al. 1999; Pozo et al. 2002). The fact that B. mycoides Bac J naturally establishes itself and proliferates on the sugar beet leaf could be an indication that it is involved in a mutualistic association with the plant, as seen in other Bacillus spp.-plant interactions (Beattie 2002). Recently, the genetic basis controlling biological control agent-plant interactions has begun to emerge (Simon et al. 2001; Smith et al. 1999). In tomato, a quantitative trait locus has been identified that is linked to suppression of disease by B. cereus (Smith et al. 1999), a close relative of $B$. mycoides Bac J (von Wintzingerode et al. 1997).

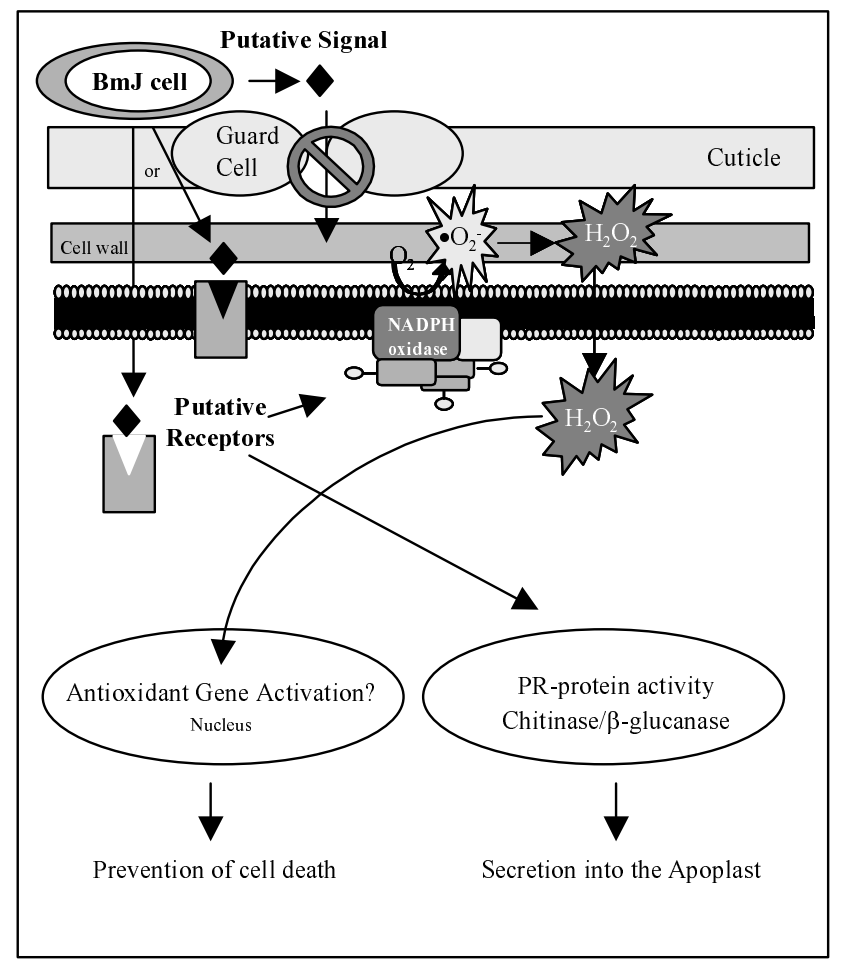

Fig. 5. Schematic representation of Bacillus mycoides isolate Bac $\mathbf{J}$ $(\mathrm{BmJ})$ interactions with sugar beet during oxidative burst and pathogenesis-related protein induction. BmJ, an epiphyte, secretes a putative signal (black diamonds) that passively enters through the cuticular waxes. Once inside the plant, the signal interacts with a putative receptor that is plasma membrane bound or cytosolic, leading to the production of superoxide anion (data not shown) and biphasic hydrogen peroxide. Chitinase and $\beta$-glucanase are produced and transported into the apoplast following BmJ-elicitation of systemic resistance. The lack of cell death following the oxidative burst could be a result of antioxidant production. 
It is possible that similar genetic recognition of $B$. mycoides Bac J exists within sugar beet.

The oxidative burst following $B$. mycoides $\mathrm{Bac} \mathrm{J}$ recognition is another example of sugar beet responding to B. mycoides Bac $\mathrm{J}$ as though it were an avirulent pathogen. Pathogen-induced oxidative burst prior to systemic resistance elicitation has been studied extensively and characterized as biphasic production of hydrogen peroxide (Baker and Orlandi 1995; Cessna et al. 2000; Glazener et al. 1996; Jabs et al. 1997; Martinez et al. 2000; Rajasekhar et al. 1999; Wolfe et al. 2000). Several biological control agents have been shown to induce plant defense responses (Pal et al. 2001; van Loon and Pieterse 2002); however, to date, it has not been determined if the elicitation of systemic resistance in these cases is preceded by an oxidative burst. To study hydrogen peroxide concentrations in intact leaf tissue, the phenol red oxidation method was substituted for the more widely employed luminol-dependent chemiluminescence approach that requires the use of protoplasts or cell suspension cultures (Glazener et al. 1991). B. mycoides Bac J elicited an oxidative burst in sugar beet similar in timing, but not intensity, to that elicited during the incompatible interactions (Fig. 2). With $B$. mycoides Bac $\mathrm{J}$, there was an approximate twofold reduction in the overall concentration of hydrogen peroxide being produced in the secondary peak (Fig. 2A and B). That difference becomes even more pronounced when it is taken into account that 100fold fewer E. carotovora pv. betavasculorum cells elicited a greater oxidative response. This data demonstrates that the oxidative burst preceding the induction of systemic resistance is not limited to plant-pathogen interactions, as shown by others' work with symbionts (Santos et al. 2001) and now our contribution with Bacillus biological control agent induction. The oxidative response was seen only following live B. mycoides Bac $\mathrm{J}$ cell treatment, a requirement for effective disease control as well (Bargabus et al. 2002). Furthermore, the Bacillus sp. isolate incapable of systemic resistance induction failed to elicit a biphasic hydrogen peroxide production curve. Both facts go to support the hypothesized production and release of a unique signaling molecule from B. mycoides Bac J (Fig. 5) as opposed to exopolysaccharides or generic microbial metabolite produced by all Bacillus spp. serving as inducers of systemic resistance induction. Additionally, the ineffectiveness of dead B. mycoides Bac J and nonsystemic resistance inducing Bacillus spp. treatment demonstrates that the secondary burst of hydrogen peroxide plays a role in the establishment of sugar beet immunity.

In many instances, the biphasic hydrogen peroxide production during the oxidative burst has been tied to the orchestration of hypersensitive cell death (Dat et al. 2003; de Pinto et al. 2002). However, several reports now have indicated that the oxidative burst and hypersensitive response occur independently (Baker and Orlandi 1995; Dorey et al. 1999; Glazener et al. 1996; Sasabe et al. 2000). The observation that B. mycoides Bac $J$ can elicit biphasic production of hydrogen peroxide in the absence of hypersensitive cell death provides more evidence to the newly emergent idea that hydrogen peroxide is not sufficient in and of itself to cause cell death. Recently, the role of hydrogen peroxide in plant defense has been shown to vary in a concentration-dependent manner. Low to moderate concentrations stimulate the production of protective antioxidant enzymes and activate systemic resistance signal transduction cascades (Solomon et al. 1999). In contrast, moderately high to extremely high levels lead to programmed cell death and necrosis respectively (Fleury et al. 2002). The B. mycoides Bac $\mathrm{J}-E$. carotovora $\mathrm{pv}$. betavasculorum comparison works well to demonstrate these points because they both effectively induce resistance to the same extent, but differentially induce cell death; therefore, our B. mycoides Bac J-sugar beet model includes the hypothesized activation of antioxidant enzymes
(Fig. 5). Other recent reports provide evidence that hydrogen peroxide is not the single, key player in cell death orchestration. Concomitant production of nitric oxide and hydrogen peroxide leads to cell death, even at concentrations that are ineffective when they occur independently of one another, further supporting synergistic interactions as a requirement for hypersensitive cell death (de Pinto et al. 2002). Nevertheless, these two chemical species act independently of one another to induce various defensive compounds (Delledonne et al. 1998). Therefore, differential production of hydrogen peroxide and nitric oxide may be the chemical basis for having different cell death responses following $B$. mycoides Bac $\mathrm{J}$ and avirulent $E$. carotovora pv. betavasculorum treatment while having no effect on systemic resistance induction. Mitochondria also recently have been shown to play a central role in plant-programmed cell death (Lam et al. 2001) through the translocation of cytochrome $c$ into the cytosol that ultimately leads to procaspase cleavage and activation of a caspase cascade (Balk et al. 1999). The latter chemical changes in the host may be occurring following priming with the avirulent $E$. carotovora pv. betavasculorum isolates; however, it is unlikely that mitochondrial signaling plays a role $B$. mycoides Bac J-elicited systemic resistance because there is an absence of cell death.

Future work could include the elucidation of the underlying chemical differences leading to and preventing cell death in sugar beet following treatment with the avirulent Erwinia isolates and B. mycoides Bac J, respectively. Examination of the localized production of antioxidant enzymes, caspase activation, and nitric oxide production would be included in these studies. Finally, the stage has been set for future isolation and characterization of putative $B$. mycoides Bac J effector molecules and sugar beet receptors.

\section{MATERIALS AND METHODS}

\section{Plant cultures.}

Sugar beet cvs. USH11 and C40 (provided by R. Lewellen, United States Department of Agriculture-Agricultural Research Service [USDA-ARS], Salinas, CA, U.S.A.) were seeded into flats for germination, transplanted into $10-\mathrm{cm}$ pots after 1 week, and grown in the glasshouse for 6 weeks in MSU (Montana State University) mix (one-third sand, one-third peat, and one-third topsoil plus the wetting agent Aquagrow 2000). Plants were maintained at $24 \pm 2{ }^{\circ} \mathrm{C}$ and were watered and fertilized twice a week to maintain vigorous growth. The photoperiod was $16 \mathrm{~h}$ of light and $8 \mathrm{~h}$ of dark.

\section{Bacterial cultures.}

B. mycoides isolate Bac $\mathrm{J}$ cells, originally isolated from sugar beet leaves from Sidney, MT in 1994, were prepared as previously described (Bargabus et al. 2002). For experiments testing dead cells, B. mycoides Bac J suspensions were diluted to $1 \times 10^{8} \mathrm{CFU} / \mathrm{ml}$ and autoclaved for $30 \mathrm{~min}$. Autoclaved cells were tested for lack of viability by plating $100 \mu$ onto each of three plates of tryptic soy agar.

E. carotavora pv. betavasculorum isolates 1 and 6 were obtained from Dr. Robert Lewellen (USDA-ARS). E. carotovora pv. betavasculorum isolates 1 and 6 are avirulent on C40 and USH11, respectively. Fresh cell preparations were grown on tryptic soy agar for 24 to $48 \mathrm{~h}$. Cells were harvested into 10 $\mathrm{ml}$ of distilled water and diluted to $1 \times 10^{8} \mathrm{CFU} / \mathrm{ml}$.

B. pumulis isolate BMH5E-40 originally was isolated from the sugar beet rhizosphere in Sidney, MT in 1997. Fresh cell preparations were grown in tryptic soy broth for $48 \mathrm{~h}\left(28^{\circ} \mathrm{C}\right)$. Cells were centrifuged $15 \mathrm{~min}$ at $10,000 \times g\left(4^{\circ} \mathrm{C}\right)$, washed with sterile water $(2 \times)$, and resuspended in distilled water at a concentration of $1 \times 10^{8}$ cells $/ \mathrm{ml}$. 


\section{Fungal culture.}

C. beticola (wild-type isolate EC3, isolated in Sidney, MT in 1996) was grown on potato dextrose agar (Difco Laboratories, Detroit) for a minimum of 2 weeks at $22 \pm 2^{\circ} \mathrm{C}$, with exposure to fluorescent or natural light for at least 1 week to promote sporulation. Spores were harvested at $\approx 30$ days after plating in $0.1 \%$ carboxymethyl cellulose by scraping with a cotton swab, counted with a hemacytometer, and adjusted to $1 \times 10^{4}$ spores $/ \mathrm{ml}$.

\section{Disease control assay.}

Typically, treatment of sugar beet with Erwinia spp. is carried out by stab inoculation into the petiole; whereas, in previous studies, B. mycoides Bac $\mathrm{J}$ was applied to leaves by spraying (Bargabus et al. 2002). Results from the experiments described below indicated that syringe infiltration was effective for all cultures as a means of standardizing the treatment method for disease control, hydrogen peroxide, and cell death assays. B. mycoides Bac J $\left(1 \times 10^{2}, 1 \times 10^{4}, 1 \times\right.$ $10^{6}$, and $\left.1 \times 10^{8} \mathrm{CFU} / \mathrm{ml}\right)$, E. carotovora $\mathrm{pv}$. betavasculorum isolate $1\left(1 \times 10^{2}, 1 \times 10^{4}, 1 \times 10^{6}\right.$, and $\left.1 \times 10^{8} \mathrm{CFU} / \mathrm{ml}\right), E$. carotovora pv. betavasculorum isolate $6\left(1 \times 10^{2}, 1 \times 10^{4}, 1\right.$ $\times 10^{6}$, and $\left.1 \times 10^{8} \mathrm{CFU} / \mathrm{ml}\right)$, and water were syringe infiltrated into the leaf surface of the leaf penultimate to the oldest first true leaf, which then was immediately bagged. Three days post treatment, the remaining untreated leaves were inoculated with $C$. beticola at $1 \times 10^{4}$ spores $/ \mathrm{ml}$. Disease severity was determined using the KWS scale (Kleinwanzler 1970) at 21 days post challenge. Three independent disease control assays were performed containing five replicates per bacterial or water treatment. The data was pooled and the mean disease severity rating was determined for each treatment. Percent disease reduction was calculated as follows: (KWS rating for water control - KWS rating for treated plant)/KWS rating for water control $\times 100$.

\section{Pathogenesis-related protein analysis.}

To evaluate elicitation of systemic resistance using stab, syringe, or spray inoculation methods for B. mycoides Bac J $(1 \times$ $\left.10^{8} \mathrm{CFU} / \mathrm{ml}\right)$, E. carotovora pv. betavasculorum isolate $1(1 \times$ $10^{6} \mathrm{CFU} / \mathrm{ml}$ ), and E. carotovora pv. betavasculorum isolate 6 $\left(1 \times 10^{6} \mathrm{CFU} / \mathrm{ml}\right)$, the production of glucanase and chitinase was determined as previously described (Bargabus et al. 2002). These enzymes are accepted molecular markers of systemic resistance induction (van Loon and van Strein 1999). Stab, syringe, and spray treatments were replicated three independent times for each bacterium, with three subsamples for each treatment. The data was pooled and the mean was determined for each treatment method with B. mycoides Bac J and E. carotovora pv. betavasculorum isolates 1 and 6 .

\section{Assay for hydrogen peroxide production.}

To examine the oxidative response of sugar beet to live and dead B. mycoides Bac J, B. pumulis isolate BMH5E-40, and $E$. carotovora pv. betavasculorum isolates 1 and 6 , hydrogen peroxide production was assayed by monitoring the oxidation of phenol red (Pick and Keisari 1980). Whole leaf disks (12 7-cm disks/reaction) were utilized to study the response and native sugar beet peroxidases carried out the oxidation reaction. Phenol red oxidation levels by bacteria and leaf disks alone were subtracted from the amount of oxidation in reactions containing both bacterial cells and leaf disks. The concentration of hydrogen peroxide $(\mathrm{mM})$ was calculated by establishing a linear standard curve with type II horseradish peroxidase (EC 1.11.1.7; Sigma, St. Louis) at 6.2 $\mu \mathrm{g} / \mathrm{ml}$ and 1 to $40 \mathrm{mM}$ hydrogen peroxide. Three replications for each plant-bacteria combination were carried out with two subsamples each. The data were pooled and the mean hydrogen peroxide concentration was determined for each time point.

\section{Signaling by Bacillus mycoides isolate Bac $\mathbf{J}$.}

To test the hypothesis that signaling between B. mycoides Bac $\mathbf{J}$ and sugar beet involved stomatal conductance of signals, hydrogen peroxide secondary peak production patterns were examined by phenol red oxidation while the stomata were closed. To confirm stomatal closure following a 15-min adjustment to green light conditions (Roscolux filter \#90; dark yellow green; $13 \%$ transmission; 480 to $580 \mathrm{~nm}$ ), leaf surfaces were painted with clear nail polish and allowed to dry, after which the nail polish was peeled off the leaf surface and examined under the microscope. These peels were compared with peels conducted on plants kept in the light, where the stomata were open. Approximately 100 stomata were observed per leaf. Plants were kept under green light or complete darkness for the entire experiment. As a positive control for the oxidative burst studies, $1 \times 10^{8}$ B. mycoides Bac $\mathrm{J}$ cells $/ \mathrm{ml}$ were syringe infiltrated into plants kept under the same green light conditions. Secondary peaks from experiments conducted in the dark were compared with secondary peaks elicited from $B$. mycoides Bac $\mathrm{J}$ syringe and spray infiltration in the light. In both sets of experiments, the background phenol red oxidation, determined using plants infiltrated or sprayed with water, was subtracted from the B. mycoides Bac J infiltrated and sprayed plants respectively. Three independent replications of each treatment were conducted and the mean was determined for each time point.

\section{Observation of cell death.}

Sugar beet leaves were syringe infiltrated with $E$. carotovora pv. betavasculorum isolate $1\left(1 \times 10^{6} \mathrm{CFU} / \mathrm{ml}\right)$, isolate $6(1 \times$ $\left.10^{6} \mathrm{CFU} / \mathrm{ml}\right)$, and B. mycoides Bac J $\left(1 \times 10^{8} \mathrm{CFU} / \mathrm{ml}\right)$. Observations of disease symptom progression were made daily for 1 month. The infiltration site and those areas surrounding the infiltration site were evaluated and photographed. This experiment was repeated on three independent occasions.

\section{ACKNOWLEDGMENTS}

This article has been assigned journal series \#2003-20 by the Montana Agricultural Experiment Station. We thank Robert Lewellen for providing us with the gift of sugar beet cvs. C40 and USH11, as well as Erwinia carotovora pv. betavasculorum isolates 1 and 6 , without which the experiments would not have been possible; Ame Strong and Rosco Laboratories Inc. for providing us with the necessary Roscolux filters for use in the signaling experiments; and Rich Stout for providing us with the stomata impression protocol.

\section{LITERATURE CITED}

Allan, A. C., Lapidot, M., Culver, J. N., and Fluhr, R. 2001. An early mosaic virus-induced oxidative burst in tobacco indicates extracellular perception of the virus coat protein. Plant Physiol. 126:97-108.

Alvarez, M. E., Pennell, R. I., Meijer, P. J., Ishikawa, A., Dixon, R. A. and Lamb, C. 1998. Reactive oxygen intermediates mediate a systemic signal network in the establishment of plant immunity. Cell 92:773784.

Baker, C. J., and Orlandi, E. W. 1995. Active oxygen in plant pathogenesis. Annu. Rev. Phytopathol. 33:299-321.

Balk, J., Leaver, C. J., and McCabe, P. F. 1999. Translocation of cytochrome $\mathrm{c}$ from the mitochondria to the cytosol occurs during heatinduced programmed cell death in cucumber plants. FEBS (Fed. Eur. Biochem. Soc.) Lett. 463:151-154.

Bargabus, R. L., Zidack, N. K., Jacobsen, B. J., and Sherwood, J. E. 2001. Elicitation of ISR by a nonpathogenic phyllosphere-inhabiting bacterium. (Abstr.) Phytopathology 91:S5

Bargabus, R. L., Zidack, N. K., Sherwood, J. E., and Jacobsen, B. J. 2002. Characterisation of systemic resistance in sugar beet elicited by 
a non-pathogenic, phyllosphere-colonizing Bacillus mycoides, biological control agent. Physiol. Mol. Plant Pathol. 61:289-298.

Beattie, G. A. 2002. Leaf surface waxes and the process of leaf colonization by microorganisms. Pages 3-26 in: Phyllosphere Microbiology. S. E. Lindow, E. I. Hecht-Poiner, and V. J. Elliott, eds. American Phytopathological Society Press, St. Paul, MN.

Bi, Y. M., Kenton, P., Mur, L., Darby, R., and Draper, J. 1995. Hydrogen peroxide does not function downstream of salicylic acid in the induction of PR protein expression. Plant J. 8:235-245.

Boller, T. 1995. Chemoperception of microbial signals in plant cells. Annu. Rev. Plant Physiol. Plant Mol. Biol. 46:189-214.

Boveris, A. 1998. Biochemistry of free radicals: from electrons to tissues. Medicina 58:350-356.

Bradley, D. J., Kjellbom, P., and Lamb, C. J. 1992. Elicitor- and woundinduced oxidative cross-linking of a proline-rich plant cell wall protein: a novel, rapid defense response. Cell 70:21-30.

Cessna, S. G., Sears, V. E., Dickman, M. B., and Low, P. S. 2000. Oxalic acid, a pathogenicity factor for Sclerotinia sclerotiorum, suppresses the oxidative burst of the host plant. Plant Cell 12:2191-2120.

Chen, Z., Silva, H., and Klessig, D. F. 1993. Active oxygen species in the induction of plant systemic acquired resistance by salicylic acid. Science 262:1883-1886.

Cohen, Y. R. 2002. $\beta$-Aminobutrytic acid-induced resistance against plant pathogens. Plant Dis. 86:448-457.

Conrath, U., Pieterse, C. M., and Mauch-Mani, B. 2002. Priming in plant-pathogen interactions. Trends Plant Sci. 7:210-216.

Costet, L., Dorey, S., Fritig, B., and Kauffmann, S. 2002. A pharmacological approach to test the diffusible signal activity of reactive oxygen intermediates in elicitor-treated tobacco leaves. Plant Cell Physiol. 43:91-98.

Dat, J. F., Pellinen, R., Van De Cotte, B., Langebartels, C., Kangasjarvi, J., Inze, D., and van Breusegem, F. 2003. Changes in hydrogen peroxide homeostasis trigger an active cell death process in tobacco. Plant J. 33:621-632

Delledonne, M., Xia, Y., Dixon, R. A., and Lamb, C. 1998. Nitric oxide functions as a signal in plant disease resistance. Nature 394:585-588.

de Pinto, M. C., Tommasi, F., and De Gara, L. 2002. Changes in the antioxidant systems as part of the signaling pathway responsible for the programmed cell death activated by nitric oxide and reactive oxygen species in tobacco Bright-Yellow 2 cells. Plant Physiol. 130:698-708.

Dorey, S., Kopp, M., Geoffroy, P., Fritig, B., and Kauffmann, S. 1999. Hydrogen peroxide from the oxidative burst is neither necessary nor sufficient for hypersensitive cell death induction, phenylalanine ammonia lyase stimulation, salicylic acid accumulation, or scopoletin consumption in cultured tobacco cells treated with elicitin. Plant Physiol. 121:163-171.

Felix, G., Duran, J. D., Volko, S., and Boller, T. 1999. Plants have a sensitive perception system for the most conserved domain of bacterial flagellin. Plant J. 18(3):265-276.

Feugey, L., Strullu, D.-G., Poupard, P., and Simoneau, P. 1999. Induced defence response limit Harig net formation in ectomycorrhizal birch roots. New Phytol. 144:341-347.

Fleury, C., Mignotte, B., and Vayssuere, J. L. 2002. Mitochondrial reactive oxygen species in cell death signaling. Biochimie 84:131-141.

Gilchrist, D. G. 1998. Programmed cell death in plants: The purpose and promise of cellular suicide. Annu. Rev. Phytopathol. 36:393-414.

Glazener, J. A, Orlandi, E. W., and Baker, C. J. 1996. The active oxygen response of cell suspensions to incompatible bacteria is not sufficient to cause hypersensitive cell death. Plant Physiol. 110:759-763.

Glazener, J. A, Orlandi, E. W., Harmon, G. L., and Baker, C. J. 1991. An improved method for monitoring active oxygen in bacteria-treated suspension cells using luminol-dependent chemiluminescence. Physiol. Mol. Plant Pathol. 39:123-133.

Grant, J. J., and Loake, G. J. 2000. Role of reactive oxygen intermediates and cognate redox signaling in disease resistance. Plant Physiol. 124:21-29.

Hammerschmidt, R., and Kuc, J. 1982. Lignification as a mechanism for induced systemic resistance in cucumber. Physiol. Plant Pathol. 20:61-71.

Hippeli, S., Heiser, I., and Elstner, E. F. 1999. Activated oxygen and free oxygen radicals in pathology: new insights and analogies between animals and plants. Plant Physiol. Biochem. 37:167-178.

Hutchenson, S. W. 1998. Current concepts of active defense in plants. Annu. Rev. Phytopathol. 36:59-90.

Imlay, J. A. 2002. How oxygen damages microbes: oxygen tolerance and obligate anaerobiosis. Adv. Microb. Physiol. 46:111-153.

Jabs, T., Tschope, M., Colling, C., Hahlbrock, K., and Scheel, D. 1997. Elicitor-stimulated ion fluxes and $\mathrm{O}_{2}^{-}$from the oxidative burst are essential components in triggering defense gene activation and phytoalexin synthesis in parsley. Proc. Natl. Acad. Sci. U.S.A. 94:48004805 .
Jalloul, A., Montillet, J. L., Assigbetse, K., Agnel, J. P., Delannoy, E., Triantaphylides, C., Daniel, J. F., Marmey, P., Geiger, J. P., and Nicole, M. 2002. Lipid peroxidation in cotton: Xanthomonas interactions and the role of lipoxygenases during the hypersensitive reaction. Plant J. 32:1-12.

Kariola, T., Palomaki, T. A., Brader, G., and Palva, E. T. 2003. Erwinia carotovora subsp. carotovora and Erwinia-derived elicitors HrpN and PehA trigger distinct but interacting defense responses and cell death in Arabidopsis. Mol. Plant-Microbe Interact. 16:179-187.

Kleinwanzler Saatzucht Ag. Einbeck. 1970. Cercospora Tafel. KWS Saat Ag. Einbeck, Germany.

Kuc, J. 1992. Induced immunity to plant disease. Bioscience 32:854-860.

Lam, E., Kato, N., and Lawton, M. 2001. Programmed cell death, mitochondria and the plant hypersensitive response. Nature 411:848-853.

Lamb, C., and Dixon, R. A. 1997. The oxidative burst in plant disease resistance. Annu. Rev. Plant Physiol. Plant Mol. Biol. 48:251-275.

Levine, A., Pennell, R. I., Alvarez, M. E., Palmer, R., and Lamb, C. 1996. Calcium-mediated apoptosis in a plant hypersensitive disease resistance response. Curr. Biol. 6:427-437.

Levine, A., Tenhaken, R., Dixon, R., and Lamb, C. 1994. $\mathrm{H}_{2} \mathrm{O}_{2}$ from the oxidative burst orchestrates the plant hypersensitive disease resistance response. Cell 79:583-593.

Mackerness, S., John, C. F., Jordan, B., and Thomas, B. 2001. Early signaling components in ultraviolet-B responses: distinct roles for different reactive oxygen species and nitric oxide. FEBS (Fed. Eur Biochem. Soc.) Lett. 489:237-242.

Martinez, C., Baccou J. C., Bresson, E., Baissac, Y., Daniel, J. F., Jalloul, A., Montillet, J. L., Geiger J. P., Assigbetse, K., and Nicole, M. 2000. Salicylic acid mediated by the oxidative burst is a key molecule in local and systemic responses of cotton challenged by an avirulent race of Xanthomonas campestris pv. malvacearum. Plant Physiol. 122:757766.

Pal, K. K., Tilak, K. V., Saxena, A. K., Dey, R., and Singh, C. S. 2001. Suppression of maize root diseases caused by Macrophomina phaseolina, Fusarium moniliforme and Fusarium graminearum by plant growth promoting rhizobacteria. Microbiol. Res. 156:209-223.

Parker, J. E., and Coleman, M. J. 1997. Molecular intimacy between proteins specifying plant-pathogen recognition. Trends Biochem. Sci. 22:291-296.

Peng, M., and Kuc, J. 1992. Peroxidase-generated hydrogen peroxide as a source of antifungal activity in vitro and on tobacco leaf disks. Phytopathology 82:696-699.

Pick, E., and Keisari, Y. 1980. A simple colorimetric method for the measurement of hydrogen peroxide produced by cells in culture. $\mathrm{J}$ Immunol. Methods 38:161-170.

Pozo, M. J., Cordier, C., Dumas-Gaudot, E., Gianinazzi, S., Barea, J. M., and Azcon-Aguilar, C. 2002. Localized versus systemic effect of arbuscular mycorrhizal fungi on defence responses to Phytophthora infection in tomato plants. J. Exp. Bot. 53:525-534.

Rahme, L. G., Mindrinos, M. N., and Panopaulos, N. J. 1992. Plants and environmental sensory signals control the expression of hrp genes in Pseudomonas syringae pv. phaseolicola. J. Bacteriol. 174:3499-3507.

Rajasekhar, V. K., Lamb, C., and Dixon, R. A. 1999. Early events in the signal pathway for the oxidative burst in soybean cells exposed to avirulent Pseudomonas syringae pv. glycinea. Plant Physiol. 120:1137-1146.

Santos, R., Heouart, D., Sigaud, S., Touati, D., and Puppo, A. 2001. Oxidative burst in alfalfa-Sinorhizobium meliloti symbiotic interaction. Mol. Plant-Microbe Interact. 14 86-89.

Sasabe, M., Takeuchi, K., Kamoun, S., Ichinose, Y., Govers, F., Toyoda, K., Shiraishi, T., and Yamada, T. 2000. Independent pathways leading to apoptotic cell death, oxidative burst and defense gene expression in response to elicitin in tobacco cell suspension culture. Eur. J. Biochem. 267:5005-5013.

Simon, H. M., Smith, K. P., Dodsworth, J. A., Guenthner, B., Handelsman, J., and Goodman, R. M. 2001. Influence of tomato genotype on growth of inoculated and indigenous bacteria in the spermosphere. Appl. Environ. Microbiol. 67:514-520.

Smith, K. P., Handelsman, J., and Goodman, R. M. 1999. Genetic basis in plants for interactions with disease-suppressive bacteria. Proc. Natl Acad. Sci. 96:4786-4790.

Solomon, M., Belenghi, B., Delledonne, M., Menachem, E., and Levine, A. 1999. The involvement of cysteine protease inhibitor genes in the regulation of programmed cell death in plants. Plant Cell 11:431-443.

Stankiewicz, M., and Krezel, Z. 1984. Studies on the antibiosis of Streptomyces roseofulvus 210 against Bacillus mycoides infection of sugar beet. Acta Microbiol. Pol. 33:257-257-262.

Tally, A., Oostendorp, M., Lawton, K., Staub, T., and Bassi, B. 1999. Commercial development of elicitors of induced resistance to pathogens. Pages 299-318 in: Induced Defenses Against Pathogens and 
Herbivores. A. A. Agrawal, S. Tuzun, and E. Bent, eds. American Phytopathological Society Press, St. Paul, MN, U.S.A.

van Breusegem, F., Vranova, E., Dat, J. F., and Inze, D. 2001. The role of active oxygen species in plant signal transduction. Plant Sci. 161:405414.

van Camp, W., Van Montagu, M., and Inze, D. 1998. $\mathrm{H}_{2} \mathrm{O}_{2}$ and NO: redox signals in disease resistance. Trends Plant Sci. 3:330-334.

van Loon, L. C., and van Strein, E. A. 1999. The families of pathogenesis-related proteins, their activities, and comparative analysis of PR-1 type proteins. Physiol. Mol. Plant Pathol. 55:85-97.

van Loon, L. C., and Pieterse, C. M. J. 2002. Biological control agents in signaling resistance. Pages 355-386 in: Biological Control of Crop Diseases. S. S. Gnanamanickan, ed. Mercel Dekker, Inc., New York.

Venisse, J.-S., Malnoy, M., Faize, M., Paulin, J.-P., and Brisset, M.-N. 2002. Modulation of defense responses of Malus spp. during compati- ble and incompatible interactions with Erwinia amylovora. Mol. PlantMicrobe Interact. 15:1204-1212.

Von Wintzingerode, F., Rainey, F. A., Kroppenstedt, R. M., and Stackebran, E. 1997. Identification of environmental strains if Bacillus mycoides by fatty acid analysis and species-specific $16 \mathrm{~S}$ and rDNA oligonucleotide probe. FEMS (Fed. Eur. Microbiol. Soc.) Microbiol. Ecol. 24:201-209.

Whitney, E. D., and Duffus, J. E. 1991. Compendium of Beet Disease and Insects. American Phytopathological Society Press, St. Paul, MN, U.S.A.

Wolfe, J., Hutcheon, C. J., Higgins, V. J., and Cameron, R. K. 2000. A functional gene-for-gene interaction is required for the production of an oxidative burst in response to infection with avirulent Pseudomonas syringae pv. tomato in Arabidopsis thaliana. Physiol. Mol. Plant Pathol. 56:253-261. 